\title{
Palynology: History and Systematic Aspects
}

The History of Palynology - 4

Categories, Classification Systems and Systematic

Value of Pollen Features - 9

Future Perspective - 16

References - 18 
Palynology is the science of palynomorphs, a general term for all entities found in palynological preparations (e.g., pollen, spores, cysts, diatoms). A dominating object of the palynomorph spectrum is the pollen grain. The term palynology was coined by Hyde and Williams (1955; Fig. 1). It is a combination of the Greek verb paluno ( $\Pi \alpha \lambda \hat{v} \nu \omega$, "I strew or

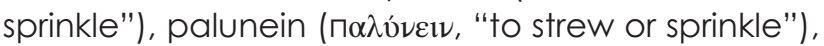
the Greek noun pale ( $\Pi \alpha \lambda \eta$, in the sense of "dust, fine meal," and very close to the Latin word pollen, meaning "fine flour, dust"), and the Greek noun

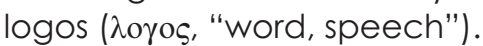

\section{The History of Palynology}

A ssyrians are said to have known the principles of pollination (they practiced hand pollination of date palms), but it is unclear if they recognized the nature of pollen itself. The invention of the first microscopes and especially the compound microscope in the late sixteenth century represents the starting point of a new fascinating era. Some of the most important findings and scientists within the long tradition of light microscopy are mentioned here. For a more comprehensive overview, see Wodehouse (1935) and Ducker and Knox (1985).

Following the invention of the simple microscope by J. Janssen and Z. Janssen in 1590, the first com- pound microscope was developed by Hooke (1665). This was an important contribution to the study of pollen morphology. Malpighi in his "Anatomia Plantarum" was the first to describe pollen grains as having germination furrows while Grew noted in his famous work "The Anatomy of Plants" the constancy of pollen characters within the same species (Fig. 2; Grew 1682; Malpighi 1901). They are both considered the founders of pollen morphology. Camerarius described several pollination experiments and communicated the results in his letters about plant sexuality to Valentini (Camerarius 1694). He stated that male "seed dust" is necessary for seed development. Von Linné (also known before his ennoblement as Carl Nilsson Linnaeus) first used the term pollen (in 1750). In the 18th and the early nineteenth centuries, there was considerable progress in pollen research and the understanding of pollination. In 1749, Gleditsch demonstrated in a spectacular experiment (Experimentum Berolinense) the central role of pollen in double fertilization. He organized the transport of an inflorescence from a male fan palm in Leipzig to a hitherto "sterile" female fan palm growing in a greenhouse in Berlin. After pollination, the female flowers produced fertile seeds for the first time in the palms lifetime (Gleditsch 1751, 1765). Placing male inflorescences within groups of female date palms for pollination was according to Theophrast already

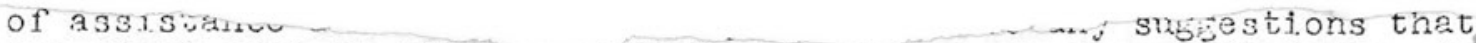
you might care to offer." (William w. rubey, Chaiman, Division of Geology and Geography, National Research Councj.1, August 30, 1944)

THE RIGHT MORD. - "The question raised by Dr. Antevs: 'Is pollen analysis the proper name for the study of pollen and its applications? cra his sugestion to replaco it by 'pollen science' interest us very much. Te ontirely agree that a new term is neecied but in vjew of the fuct that pollen analysts nomilly include in their counts tho spores of such plants as forris and mosses wo think that sone worc carrjing a wider connotation than polien seoms to je callcd for. \%e vould therefore suejest palynology, (from Greek Td.úver (paluno), to straw or sprinkle; cf. $\pi$ d $\lambda \eta$ (palé), fine mol; cosnato with Latin pollon, flour, dust): the study of pollen and other spores anc thor disporsal, and applications thereof. Te venture to hope that the sequence of consonants $p-1-n$, (sugestjing pollen, but with a diffonico) and the gonemal cuphony of the new wore may commend it to our follo": workors in this ijold. e heve boen assisted in the coining of this now word by fir. I. J. D. Richarcison, IA.A., University Collogo, Cardif." (H.A. Hyê end D. A. "̈illiams, July IS, 1944. "'al:s)

"I have been toying wj.th the lcee of' 'micno-paloobotany' as incluatng most of the work on pollen ara spores ancilso all minon constituents of mat and humus layers of vegetative remains which

Fig. 1 The right word. Excerpt from Hyde and Williams (1955). Pollen Analysis Circular no. 8, p. 6 


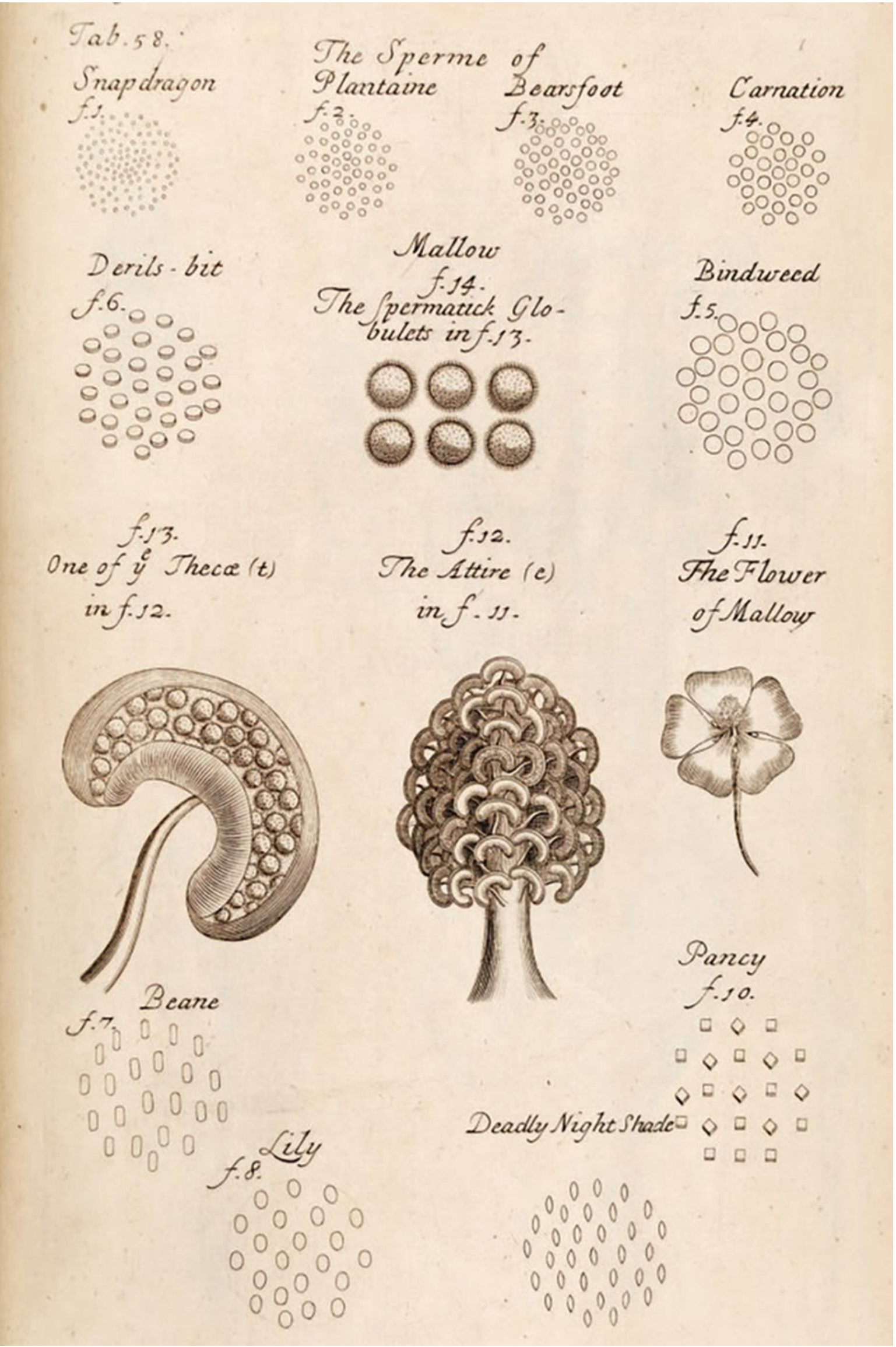

Fig. 2 First drawings of pollen. Grew (1682) "The anatomy of plants" 
practiced by the Assyrians and Egyptians. Kölreuter, together with Sprengel, the founder of research on flower biology, perceived the importance of insects in flower pollination and discovered for the first time that pollen plays an important role in determining the characters of the offspring (Kölreuter 1761-1766; Sprengel 1793). Kölreuter (1806, 1811) also discovered that the pollen wall is consisting of two distinct layers and made the first attempt to classify pollen based on their morphology. Sprengel recognized pores and furrows in the pollen wall and demonstrated the effects of cross pollination, dichogamy, and distinguished between entomo- and anemophily (Candolle and Sprengel 1821). Moreover, he also realized that every plant species has a characteristic pollen type (Sprengel 1804).

During the first half of the nineteenth century, some fundamental insights into pollen morphology and physiology were achieved. Purkinje made the first attempt for a palynological terminology by classifying pollen based on their morphology (Purkinje 1830). Wodehouse (1935) pointed out that "Purkinje's system of nomenclature deserved much more attention than was ever given to it by subsequent investigators. A system of this kind, had it been put into use, would have saved much confusion." Brown gave the first description of the origin and role of the pollen tube (Brown 1828, 1833). He credited Baver as the first observer of the pollen tube's nature, of the double wall in Asclepias pollen, and for his minute drawings of Asclepias pollen. His brother Baver, a great botanical artist, was the first to recognize compound pollen in Acacia and orchids. Cavolini described and illustrated the filiform pollen of sea grasses Zostera and Cymodocea (Cavolini 1792).

Göppert and Ehrenberg were the first to describe and depict fossil pollen grains and spores (Göppert 1837, 1848; Ehrenberg 1838). In 1834 von Mohl wrote his fundamental work entitled "Über den Bau und die Formen von Pollenkörner/On the structure and diversity of pollen grains," which was a major contribution to the knowledge of pollen structure and descriptive classification. von Mohl and Fritzsche recognized the principal layers of the pollen wall and published new surveys on pollen morphology (von Mohl 1835; Fritzsche 1837). The term pollenin goes back to von Grotthuss (1814), John (1814), Stolze (1816), and Fritzsche (1834). The terms "exine," "intine," and "Zwischenkörper" were established by Fritzsche and published in his book "Über den Pollen" (Figs. 3 and 4; Fritzsche 1837). He also demonstrated that apertures are predetermined in most angiosperm pollen while others are inaperturate. Zetzsche first coined the term "sporopollenin" to describe the resistant chemical substance present in the outer wall of both pollen grains and spores (Zetzsche and Huggler 1928; Zetzsche and Vicari 1931; Zetzsche et al. 1931). Campbell reported pollen of seagrasses (Naias and Zannichellia) to be thin walled, without exospore (exine), and two-celled. Moreover, Campbell described the mitotic division of the generative cell into two (sperm) cells (Campbell 1897). Hofmeister and Strasburger provided ground-breaking insights into the development and internal structure of pollen and fertilization (involves the fusion of a single sperm nucleus and the egg nucleus) and investigated the bi- and tricellular pollen condition of many angiosperms (Strasburger 1884; Hofmeister 1849). The role of the second sperm nucleus in the pollen tube remained unexplained until double fertilization was discovered by Guignard (1891, 1899); Nawaschin (1898). Nägeli studied the ontogeny of pollen grains within anthers and was the first to recognize the callose wall (Nägeli 1842). Schacht described differences in exine patterning, exine thickness, and apertures covered by an operculum. He also used cytochemical staining techniques to detect pollen reserves. He was also the first to cut sections of embedded pollen with razor blades for anatomical studies (Schacht 1856/59). Strasburger described the basic concepts of pollen wall development already in 1889, but major break-through in pollen wall ontogeny was achieved much later by Heslop-Harrison (1975). The first successful classification of orchidaceous plants based on pollen features was made by Lindley (1836). Later, Fischer recognized the potential of pollen morphology in aiding the phylogenetic position of angiosperms (Fischer 1890).

Paleopalynology was established at the end of the nineteenth century, when P. Reinsch published the first photomicrographs of fossil pollen and spores from Russian coals (Reinsch 1884). He also described methods for the extraction of palynomorphs from coal samples with concentrated potassium hydroxide $(\mathrm{KOH})$ and hydrofluoric acid (HF). Von Post published the first pollen diagram (profile) using exclusively arboreal pollen (von Post 1916). Already before and especially after the Second World War, Schopf as well as Potonié published their impressive publications devoted to fossil spores and pollen (e.g., Potonié 1956; Schopf 1957, 1964). Schopf established the systematic study of palynomorphs, while Potonié was one of the first who recognized the stratigraphic value of paleopalynology, applying his "turmal classification" system (Potonié 1934; see also "The Treme System and the NPCClassification" below). The rise of stratigraphic palynology started shortly before 1950 and played a prominent role in petroleum explorations during the second half of the twentieth century (Manten 1966). 
Mimoires des Lav etr. FIII. Fritrsche riber den Sollen. TabX.

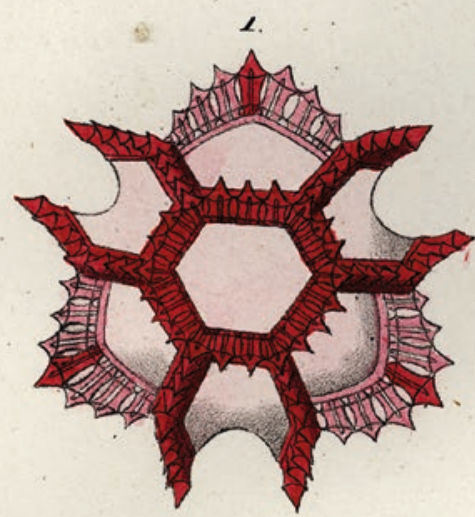

3.
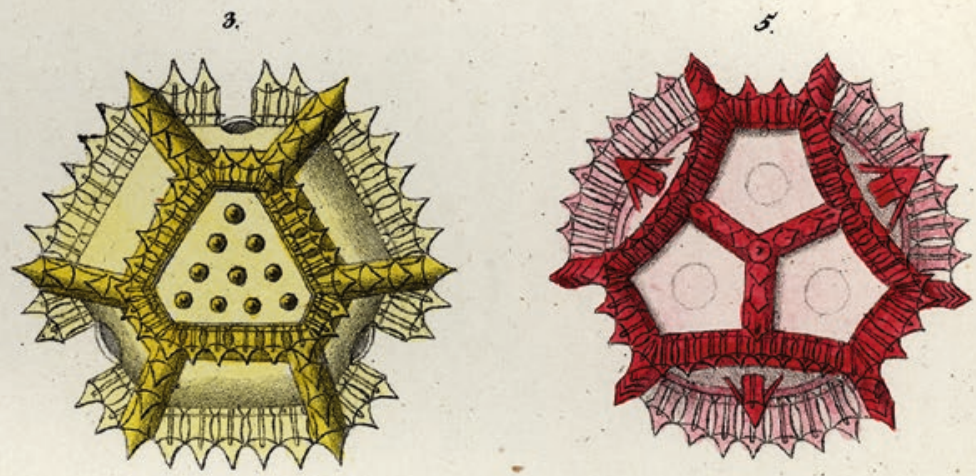

2
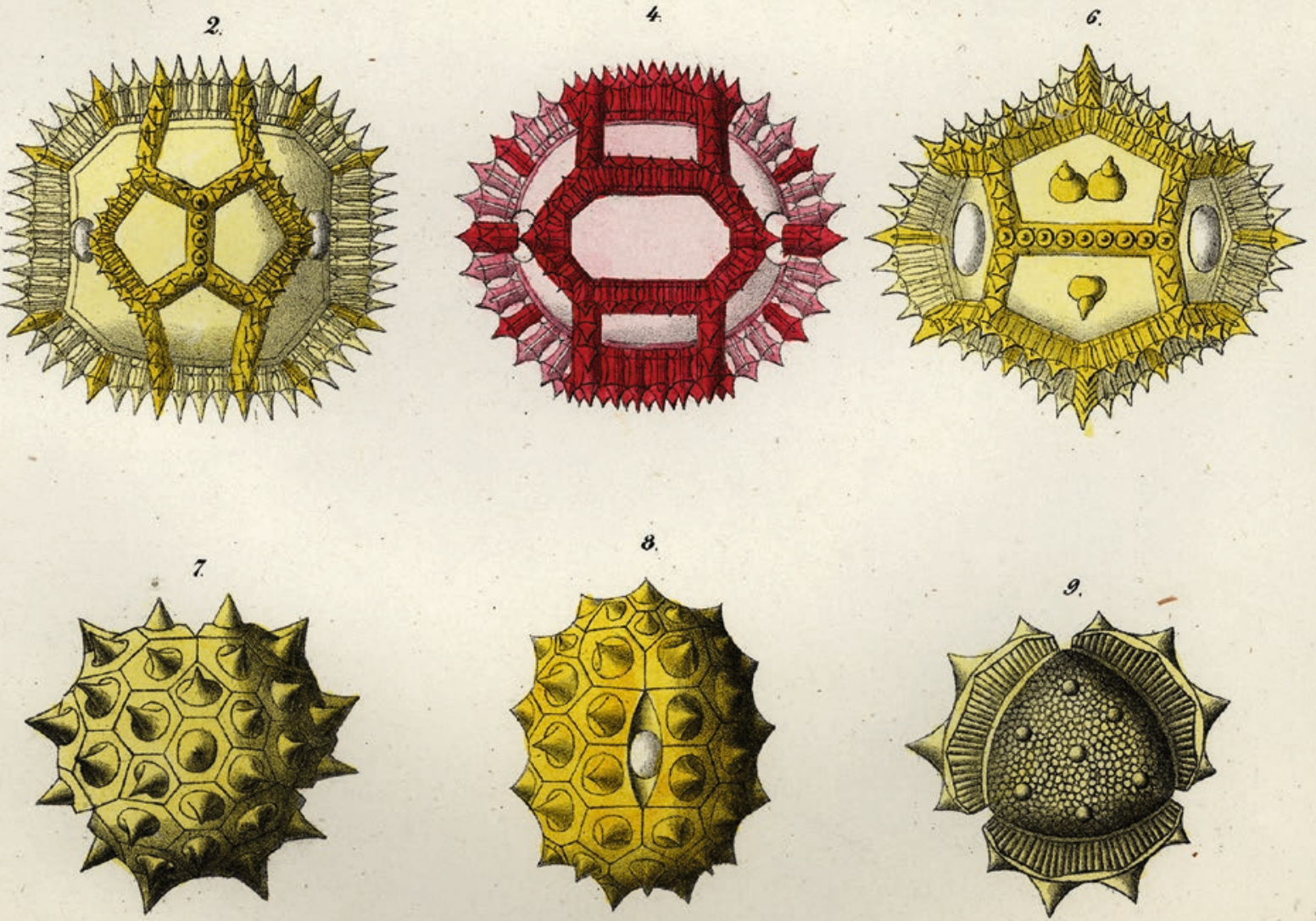

Fritrobe et Himann ad nat del.

W. Pipe in lape del.

Fig. 3 Detailed drawings of pollen. Fritzsche (1837) "Über den Pollen"

The key role of palynology in stratigraphy depends upon the fact that the natural biopolymer sporopollenin in the spore/pollen walls is extremely resistant; thus, pollen/spores are often abundantly preserved in sedimentary rocks.
The twentieth century up to ca 1960 was dominated by the skillful use of the LM, with many new findings; for example, the LO-analysis, a method for analyzing patterns of exine organization by light microscopy, focusing at different levels distinct 

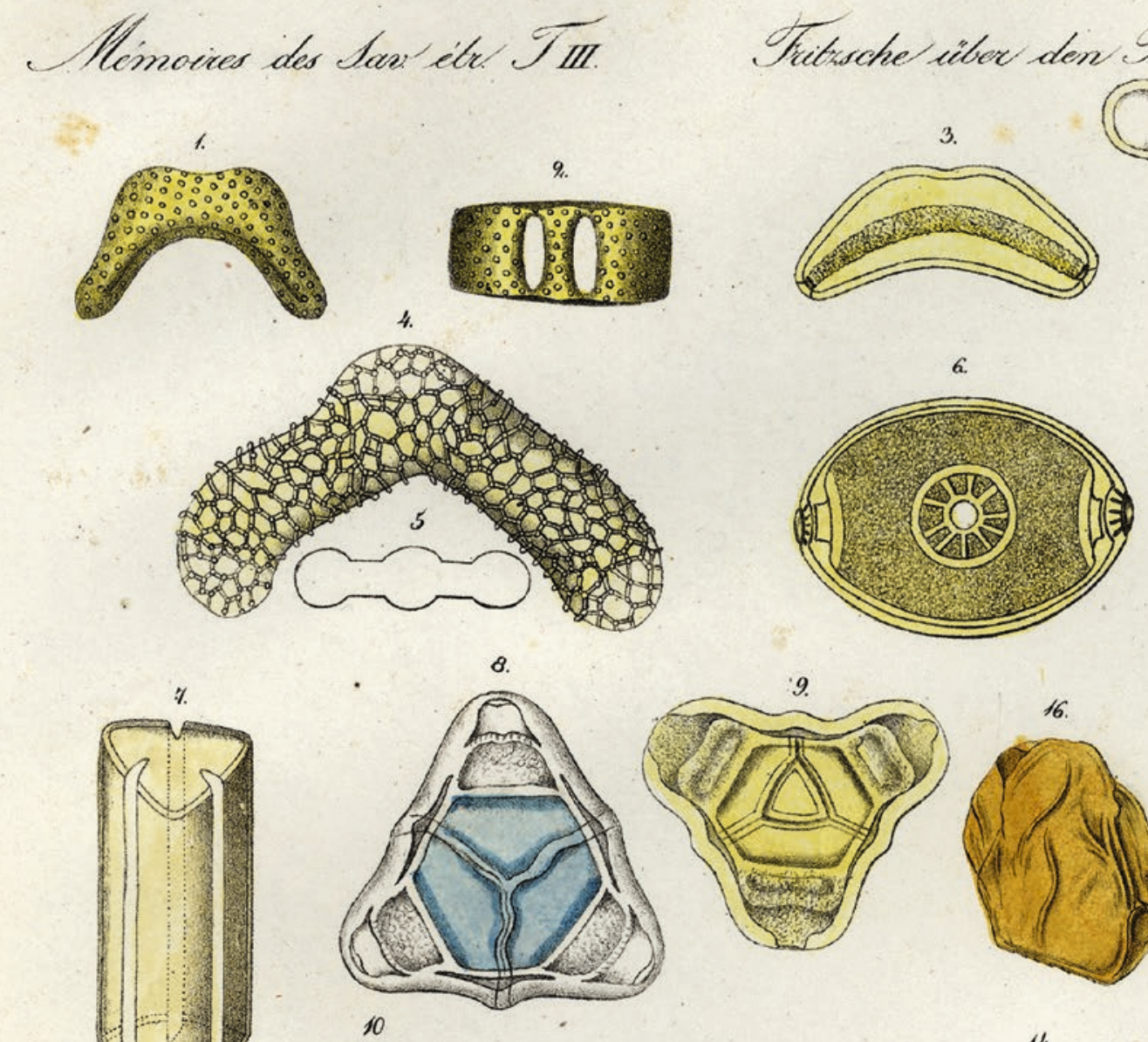

3.

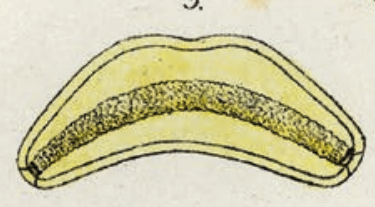

6.
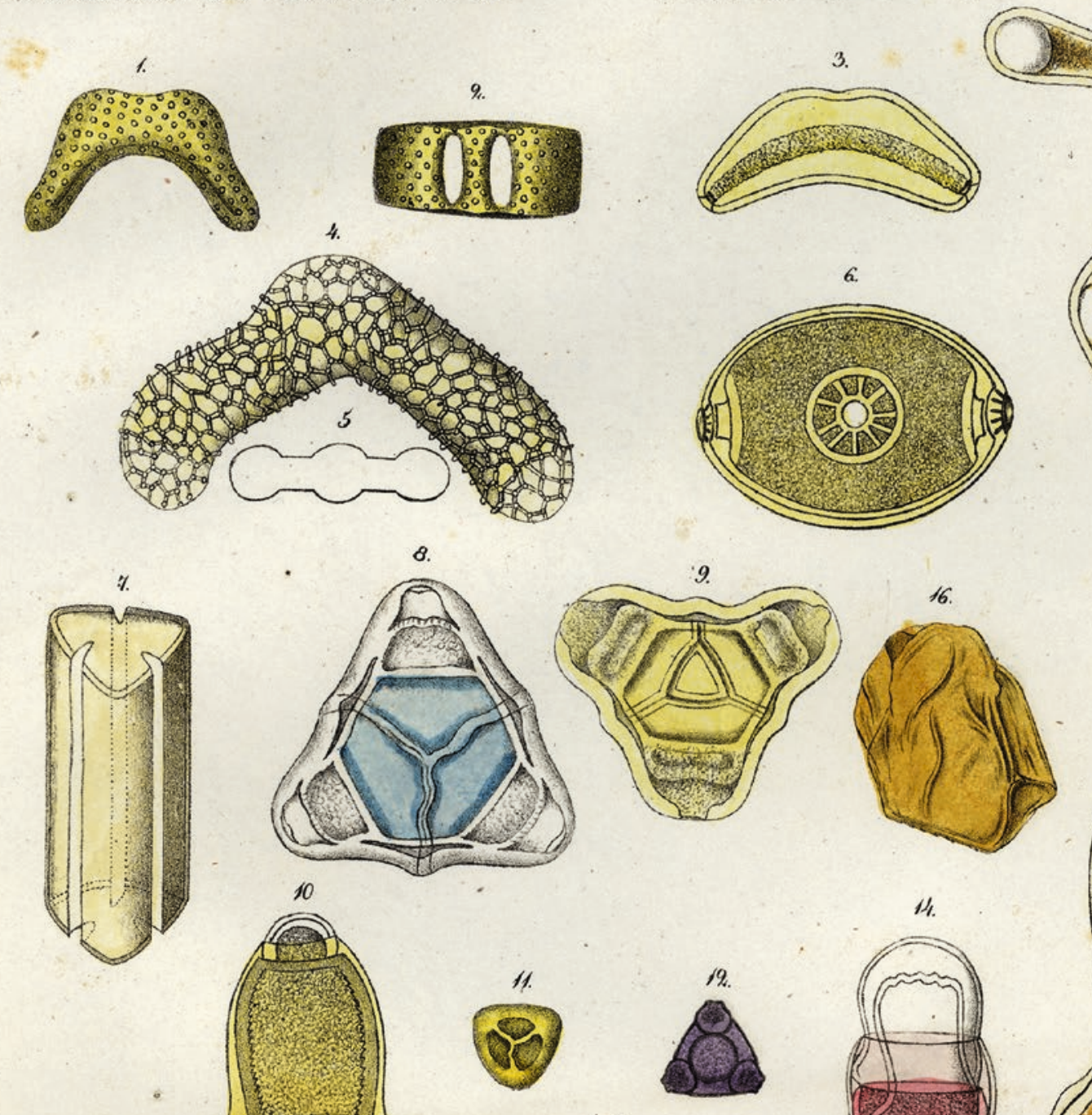

Tab XII.
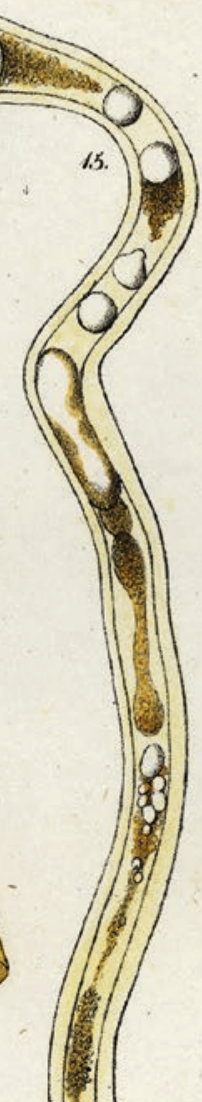
nology, biostratigraphy, copropalynology, cryopalynology, forensic palynology, iatropalynology, melissopalynology, paleopalynology, archeology, paleoclimatology, and palynotaxonomy.

Electron Microscopy with its two most important instrument types, the Transmission Electron Microscope (TEM) and the Scanning Electron Microscope (SEM), facilitated major breakthroughs in palynology. The TEM revealed new and stunning insights into pollen wall development and stratification. This prompted authors to publish new descriptions and create new terms. As pointed out by Knox: "The terminology applied to the pollen wall is daunting, especially as it has been developed from early light microscopy work, and then transposed to the images seen in the transmission and scanning electron microscopes" (Knox 1984, p. 204).

One of the first reports on the ultrastructure of recent pollen using TEM were published by $H$. Fernandez-Moran and A. O. Dahl (1952), and by K. Mühlethaler (1953). The first reports on the ultrastructure of fossil pollen were published by Ehrlich and Hall (1959; Pettitt and Chaloner (1964). During the 1950 s and early 1960s considerable progress in TEM preparation methods (from fixation to microtome sectioning and staining) took place. EM-based information on ornamentation details of pollen grains was rare up to the mid-1960s. Only TEM-based casts or replica methods were available, all of them with limited resolution and depth of focus (e.g., the single-stage carbon replica technique; Mühlethaler 1955; Bradley 1958; Rowley and Flynn 1966). The time-consuming and laborious TEM replica procedures were an obstacle to extensive surveys of pollen morphology and later replaced by SEM (Harley and Ferguson 1990). The introduction of SEM in palynology in the mid of the 1960s was a key innovation in the study of the fine relief (sculpture) of pollen and spore surfaces. Advantages of SEM include the relatively simple and rapid preparation methods and the supreme depth of focus. SEM was considered from the very first moment as the quantum leap in EM (Hay and Sandberg 1967). The first SEM micrographs of pollen grains were published by Thornhill et al. (1965) and Erdtman and Dunbar (1966). Since then palynologists have been provided with a plethora of beautiful micrographs. Like Blackmore noted "The scanning electron microscope has provided a greater impetus to palynology than any other technical development during the history of the subject." Blackmore (1992). The LM with basic and advanced equipment, such as the fluorescent super-resolution microscopy, is overcoming the Abbe limit of LM resolution (especially STED microscopy, Hell 2009). The super-resolution LM and the two main types of EM form an expedient combination of imaging techniques. The LM remains the "workhorse method" (Traverse 2007; see the compendia by Reille 1992, 1995, 1998), but is limited regarding various morphological and structural features. Therefore, the role of SEM as an essential part in illustrating exine sculpture and ornamentation cannot be overrated (Harley and Ferguson 1990). The TEM still plays an important role, for example, in elucidating the complex steps of exine formation and development (e.g., Blackmore et al. 2007, 2010; Gabarayeva and Grigorjeva 2010; Gabarayeva et al. 2010).

The first and especially the second half of the twentieth century saw palynology at its peak, combining light microscopy with electron microscopy techniques. In addition to the above-mentioned scientists, other great palynologists have also promoted our science toward its present multifaceted appearance. These include among others: B. Albert, H.-J. Beug, G. El Ghazali, F. Firbas, M. Harley, J. Jansonius, W. Klaus, G. O. W. Kremp, B. Lugardon, S. Nadot, A. Maurizio, J. Muller, S. Nilsson, J. R. Rowley, J. J. Skvarla, H. Straka, G. Thanikaimoni, R. H. Tschudy, M. van Campo, T. van der Hammen, and A. Le Thomas.

\section{Categories, Classification Systems and Systematic Value of Pollen Features}

F or the scientist, categories are essential for classifying natural characters in their diversity, defining their range and placing them in a systematic order. In addition to the theoretical concept, categorization always depends on the manner in which a feature is perceived: i.e. on the visibility of a feature, and/or their specific value. Categorization also greatly depends on the technical equipment and method(s) used, as well as on the subjective interpretation of character(s) (see "Methods in Palynology"). Thus, categorization of features is difficult to standardize. An example is the category pollen size: there is not just a natural size variation within a single anther/flower/taxon, dimensions may also vary depending on the preparation method(s) used, and the observer's evaluation. Moreover, sometimes the size of a pollen grain is just at the boundary between two adjacent pollen size categories (for size categories: see "Pollen Morphology and Ultrastructure").

When describing and categorizing pollen, two basic groupings are known from the literature: pollen type and pollen class. Pollen type is a general term categorizing pollen grains by a distinct combination of characters and is used in connection with systematics, affiliating the pollen type with a distinct 

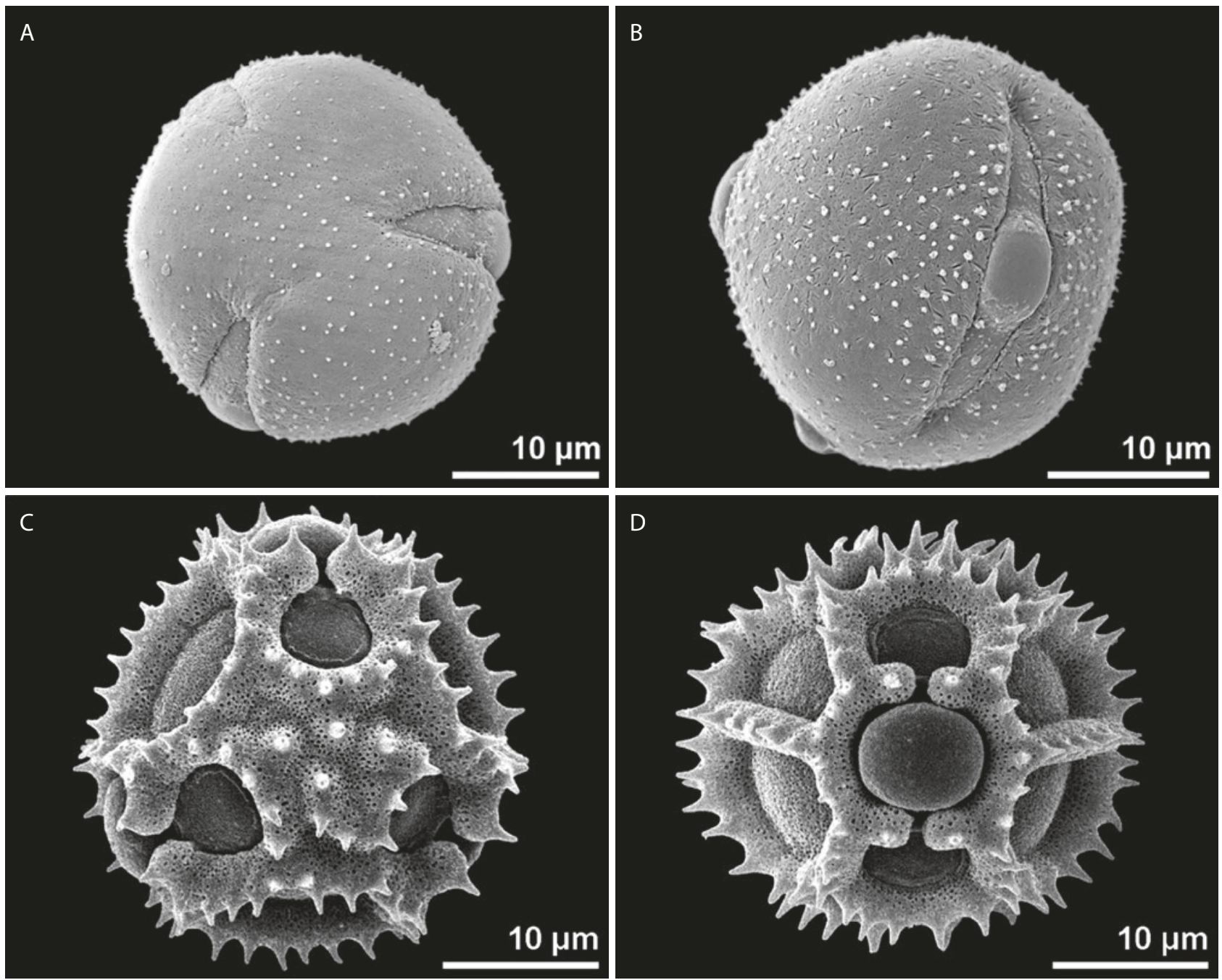

Fig. 5 Pollen type vs pollen class. A-B. Polygonum aviculare, Polygonaceae; all Polygonum pollen sharing the combined features observed here belong to the Polygonum aviculare type. This pollen can also be included in the pollen class "tricolporate". C-D. Leontodon saxatilis, Asteraceae; all Asteraceae pollen sharing the combined features observed here (lophate, tricolporate, echinate) belong to the Leontodon type, characteristic for the "Liguliflorae" group within the Asteraceae. This pollen can also be included in the pollen class "tricolporate"

taxon/a (e.g., Polygonum aviculare type/Leontodon type, Fig. 5). The term "pollen type" is sometimes (colloquially) misused: for example, Croton type, which is a distinct feature of ornamentation and is correctly termed Croton pattern.

Pollen class is an artificial grouping of pollen grains that share a single or more, distinctive characters (see "Illustrated Pollen Terms"). Pollen classes can refer to pollen units (e.g., polyads, tetrads), to shape (e.g., saccate, polygonal, heteropolar, arcus), to aperture type and location (e.g., inaperturate, sulcate, ulcerate, colpate, colporate, porate, synaperturate, spiraperturate), or to an extremely distinctive ornamentation character (e.g., lophate, clypeate). These classes can be useful in identification keys as they have a good diagnostic, although mostly no systematic, value. In general, a pollen grain may belong to more than one pollen class; in such cases, the more significant feature should be ranked first (e.g., Pistia: plicate-inaperturate, Hemigraphis: plicate-colporate, Typha: tetradsulcerate, Rhododendron: tetrads-colporate).

Many terms in palynology were coined at a time when only LM observations were available. Mainly for historical reasons, inconsequent nomenclatural applications, enumerations of synonyms, and even differing definitions have been found for one and the same term. During the twentieth century, questions of terminology became more and more problematic. The main reasons were the increasing numbers of publications in palynology, dealing with sometimes insufficiently described or "uncommon" pollen features, and simultaneously the advent of manifold applied fields of palynology. For various 
A

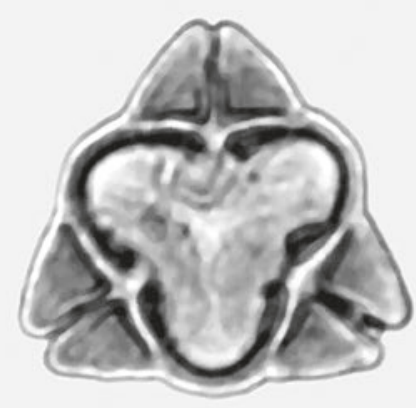

C

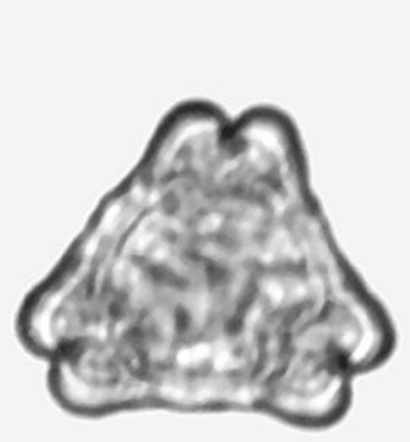

\section{B}

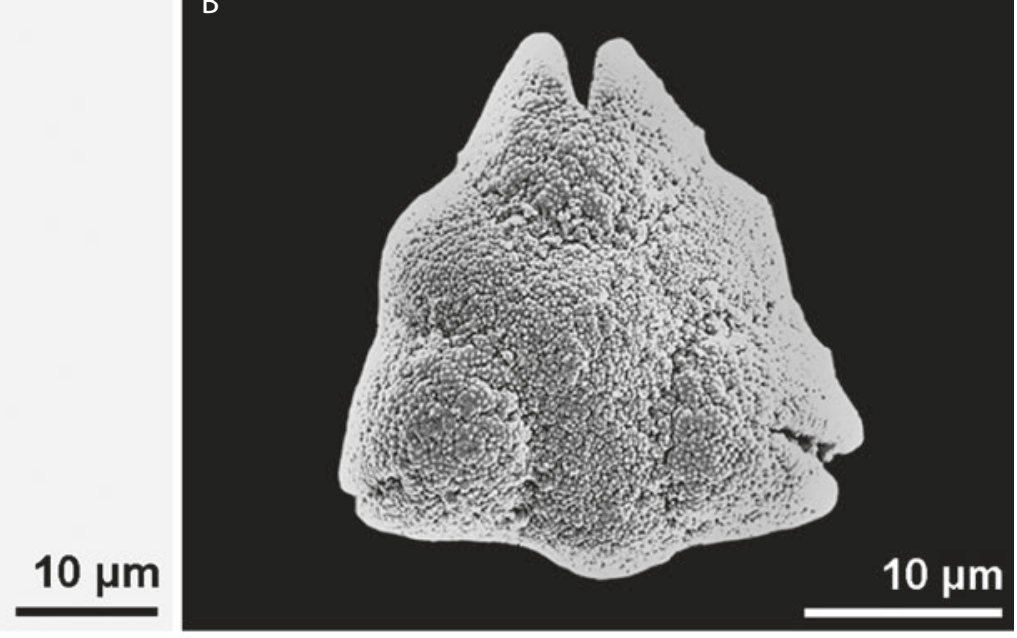

D

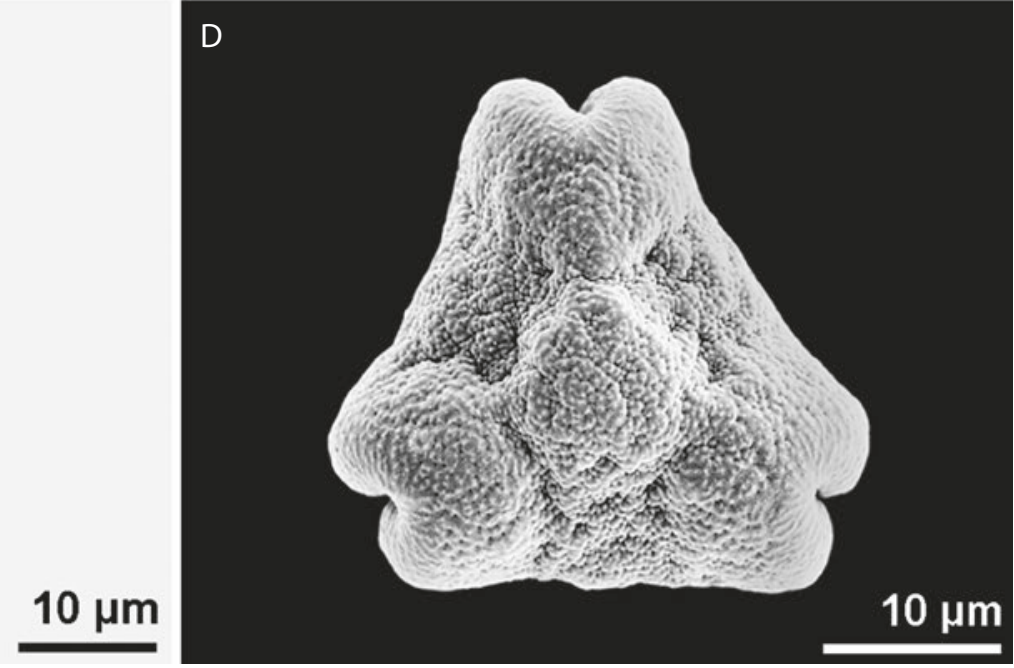

Fig. 6 Nomenclature in Paleopalynology. A. Oculopollis sp., fossil, Upper Cretaceous, Hungary, polar view. B. Oculopollis sp., fossil, Upper Cretaceous, Hungary, polar view. C. Trudopollis sp., fossil, Upper Cretaceous, Hungary, polar view. D. Trudopollis sp., fossil, Upper Cretaceous, Hungary, polar view

reasons, nearly all authors used their own terminology. Nonetheless, in the 1950s attempts were made to restrict the wording and to state the definitions of terms more precisely (Erdtman 1947; Erdtman and Vishnu-Mittre 1956). A limited list of pollen morphological terms and definitions was published as early as 1950 by Iversen and Troels-Smith. Later, Kremp (1968), in his famous encyclopedia, provided a monumental enumeration of all known terms. Reitsma (1970) took the first resolute step to overcome the problem of synonyms in palynological terminology, though unfortunately not taking into account the variation range of palynological features. Faegri and Iversen (1989, 4th ed.) restricted their glossary of terms exclusively used in their book. Moore et al. (1991, 2nd ed.) provided a glossary of selected terms used in their pollen and spore keys. Standardization came with the glossary by Punt et al. $(1994,2007)$. The main advance of their concise and comprehensive terminology is the consistent use of drawings and the critical comments on terms.

A complex category issue in (Paleo-) Palynology is the nomenclature question. In Paleopalynology, for morphotaxa often form-generic names are used. The nomenclature of form-genera is either artificial when the relationship is not known at all (e.g., Oculopollis and Trudopollis from the Normapolles group, Fig. 6), or semi-biological, when reference to an extant taxon is suspected but not proven (e.g., Liliacidites). However, if reference to extant taxa is certain, then a biological nomenclature is possible (e.g., Quercus sp.).

\section{The Turmal System}

A quite different classification and nomenclature is Potonié's turmal system. This is an artificial, informal, neutral suprageneric classification scheme for fossil 
(especially Carboniferous or Permian) pollen and spores. It is subdivided into a hierarchy of progressively finer units (ranks): anteturma, turma, subturma, infraturma, subinfraturma, and corresponds mostly to morphological features (for details see Traverse 2007).

\section{The Treme System and the NPC-Classification}

The "-treme system" of aperture configuration as an alternative or an addition to the traditional nomenclature was introduced by Erdtman and Straka (1961). The suffix-treme is derived from trema (pl. tremata) and is synonymous with aperture. In combination with prefixes such as cata-, ana-, zono-, and panto-, the position of germination sites in relation to pollen polarity can be designated. Catatreme indicates the proximal, anatreme the distal, zonotreme the equatorial, and pantotreme the global position of apertures. Other prefixes such as mono-, di-, tri-, tetra- indicate the number of apertures irrespective of their position.

The NPC-classification by Erdtman and Straka (1961), resting upon the -treme system, is a morphological system for classifying pollen and spores. This system is based on the aperture features: their number $(N)$, position $(P)$, and character $(C)$. Their NPC-system for spore/pollen classification was used as a diagnostic tool in systematics. As an example, the three apertures $\left(\mathrm{N}_{3}\right)$ of pollen grains, having a zonotreme position $\left(\mathrm{P}_{4}\right)$ and being colporate $\left(\mathrm{C}_{5}\right)$ have the NPC-formula 345 (Fig. 7; Erdtman and Straka 1961). Taxa with the same general NPCformula are grouped together, those showing a different formula, separately. This system does not work in, e.g., heteroaperturate or inaperturate (formula 000) pollen, or pollen tetrads. Unfortunately, the NPC-system ignores other pollen characters including shape and ornamentation that are indispensable for a complete description.

\section{Systematic Value of Pollen Features}

One of the main research interests in palynology focuses on the taxon-specific patterns of the pollen wall, how they developed and evolved. Moreover, pollen can provide phylogenetic evidence important to plant systematics (Hesse and Blackmore 2013). The reconstruction of phylogenies has continuously developed. The advances in modern phylogenetic approaches are resulting in constant changes in plant systematics, even whole genomes are being used together with multiple DNA analyses for a better insight into relationships (Stuessy and Funk 2013). Critically evaluated pollen features may be a useful tool for systematics with a significant diagnostic value, supporting or contradicting the results of molecular studies ("The palynological compass" sensu Blackmore 2000; Hesse and Blackmore 2013). Palynological features are very valuable, especially in delimiting taxa (Ulrich et al. 2012). Regarding multiple-gene tree studies with conflicting results, pollen data combined with other morphological evidence (e.g., floral characters) have more recently become an important indicator of which tree may be the best representative (Stuessy and Funk 2013; Ulrich et al. 2012, 2013). Furthermore, pollen morphological studies proved to be indispensable for the understanding of evolutionary
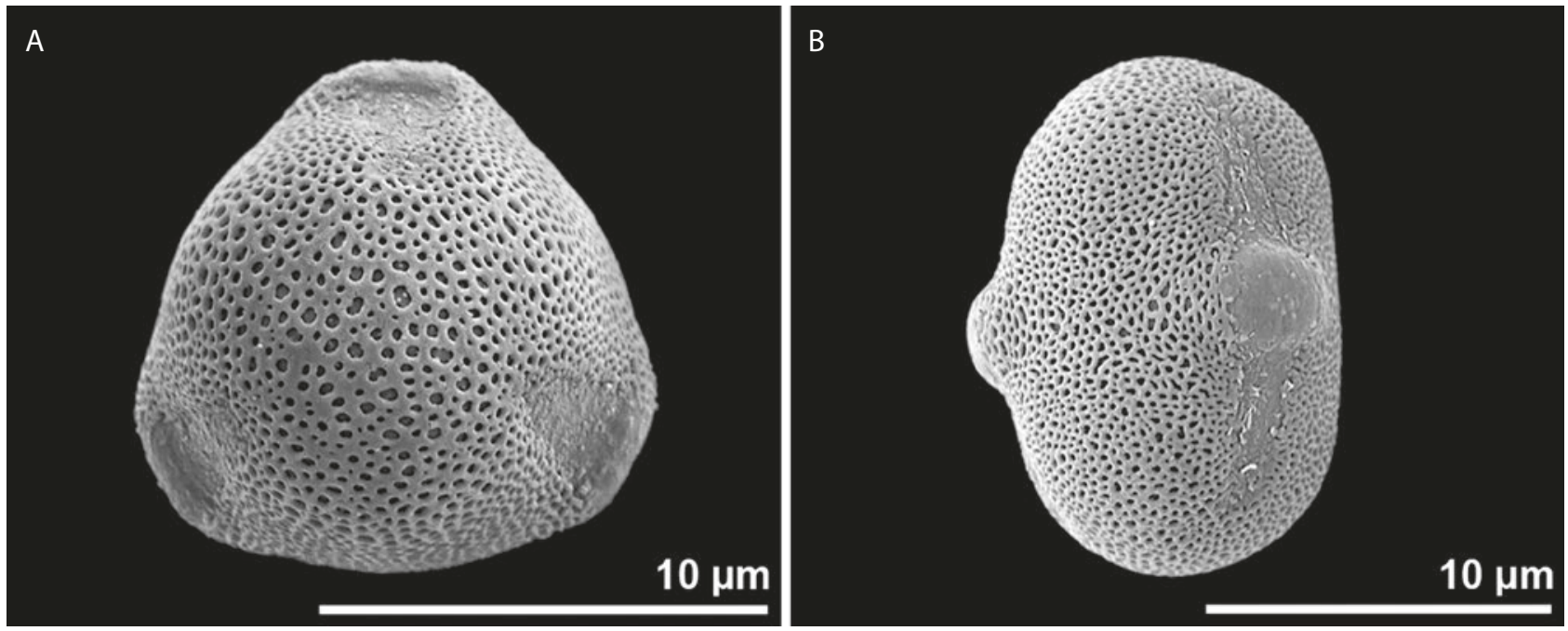

Fig. 7 NPC-classification of pollen. A-B. Androsace chamaejasme, Primulaceae, a tricolporate pollen with the formula $\mathrm{N}_{3} \mathrm{P}_{4} \mathrm{C}_{5}$ 
processes and systematics. For taxonomic studies, pollen features that have value for the lower and higher taxonomic levels should be obtained by a combined study using LM, SEM, and TEM (Stuessy 1979).

Alternation of generations is a unique feature of plants that occurs in green algae, mosses, ferns, gymnosperms, and angiosperms. Pollen grains develop in anthers as the result of meiosis and mitoses (two in angiosperms, three to five in gymnosperms) and represent an extra generation, the highly reduced male gametophyte. Therefore, pollen grains are not simply small parts of a plant like leaves or seeds; they are the complete (hidden) haploid counterpart to the more dominant plant, which represents the diploid generation (Kessler and Harley 2004). During dispersal, pollen grains are completely separated from the parent plant and perfectly adapted for their role - the transfer of male genetic material - and are able to resist hostile environmental stresses on their way to the female flower parts. Usually, pollen does not suffer to the same extent from the various and harsh selective pressures to which the diploid plant is subjected. Because selective pressures (e.g., temperature, precipitation) upon pollen characters are predominantly absent or low, compared to those on the diploid plant, pollen features may remain constant for millions of years, meaning pollen features can be conservative and of taxonomic value (Wodehouse 1928, 1935; Hao et al. 2001; Grímsson et al. 2014, 2016, 2017a, b). Therefore, identical and rare conditions in fossil vs recent pollen probably belong to only one group and were not invented independently in distant groups (e.g., fossil Spinizonocolpites pollen and recent Nypa pollen, Arecaceae; Zetter and Hofmann 2001; Gee 2001). Selective pressures might concern especially the pollen aperture number, but also the pollen sculpture and the mode of pollination ecology (Furness and Rudall 2004). Pollen features are, if used for a systematic purpose, at least as important as any other morphological character of the diploid generation. For this reason pollen morphology claims a crucial role in, e.g., systematics and palynostratigraphy, for example in elucidating the early history of angiosperms. Angiosperm pollen from the Early Cretaceous are usually sulcate (typical for basal angiosperms) with a columellate infratectum (which is restricted to angiosperms). The first appearance of dispersed tricolpate pollen, typical for eudicots, is not known before the latest Barremian, is rare in the Aptian of Southern Laurasia and Northern Gondwana, but is ubiquitous in the Albian of both provinces. Tricolporate pollen appears first in the late Albian, and triporate pollen in the middle
Cenomanian (Doyle and Endress 2010; Friis et al. 2011; Doyle 2012). For a detailed overview of structural pollen diversification and of the stratigraphic appearance of major angiosperm pollen types during the Cretaceous, see Friis et al. (2011) and Mendes et al. (2014).

Palynological data may be helpful at all levels of systematics, especially in angiosperms (c.f. Stuessy 2009). When pollen of a taxon (representing family/ ies or genus/era) is characteristic and similar among species they are termed stenopalynous (Fig. 8), and occur, for example, in Poaceae, Lamiaceae, Asclepiadaceae, Brassicaceae, Asteroideae, and Cichorioideae. On the contrary, eurypalynous (Fig. 9) taxa are heterogeneous and pollen can vary among others in size, aperture, and in exine stratification. Examples for eurypalynous groups are Acanthaceae (Sarawichit 2012) and Araceae (Harley and Baker 2001; Ulrich et al. 2017).

At the highest taxonomic level (e.g., angiosperms vs gymnosperms, dicots vs monocots), a columellate exine condition occurs exclusively in angiosperms. A lamellate endexine is typical for gymnosperms, whereas the angiosperm endexine is usually not lamellate, except in immature stages (Orobanche hederae). But in very few cases there is a continuously lamellate endexine present, like in Ambrosia (Furness and Rudall 1999a, b, Weber and Ulrich 2010). In inaperturate pollen of Araceae the endexine is exceptionally thick and spongy, which may be a functional benefit and of systematic value. A strong phylogenetic signal comes from the aperture arrangement: the "tricolpate" condition is a synapomorphy for eudicots, tricolporate pollen occurs only in core eudicots, while sulcate pollen is a plesiomorphic condition in basal angiosperms (Nadot et al. 2006). Palynologists have long wondered about the two fundamental evolutionary shifts occurring at the base of the eudicot clade, both in aperture position (from distal to equatorial) and number (from one to three or more). Most probably, these changes in pollen morphology have a systematic and simultaneously a functional background. The shift from a distal, single aperture to equatorially or globally situated apertures, increases the number of possible germination sites (Furness and Rudall 2004). Pollen morphology does not support sharp delimitation between dicots and monocots, as dicotyledonous pollen characters also occur in some monocots and conversely. In early-diverging angiosperms the formation of pollen features appears to be more plastic than in dicots (especially in eudicots). Manifold combinations of pollen features are typical for basal angiosperms and even for the most basal eudicots, the Ranunculales. All of them are more or less eurypalynous. In contrast, late-divergent eudicots are often stenopalynous and 

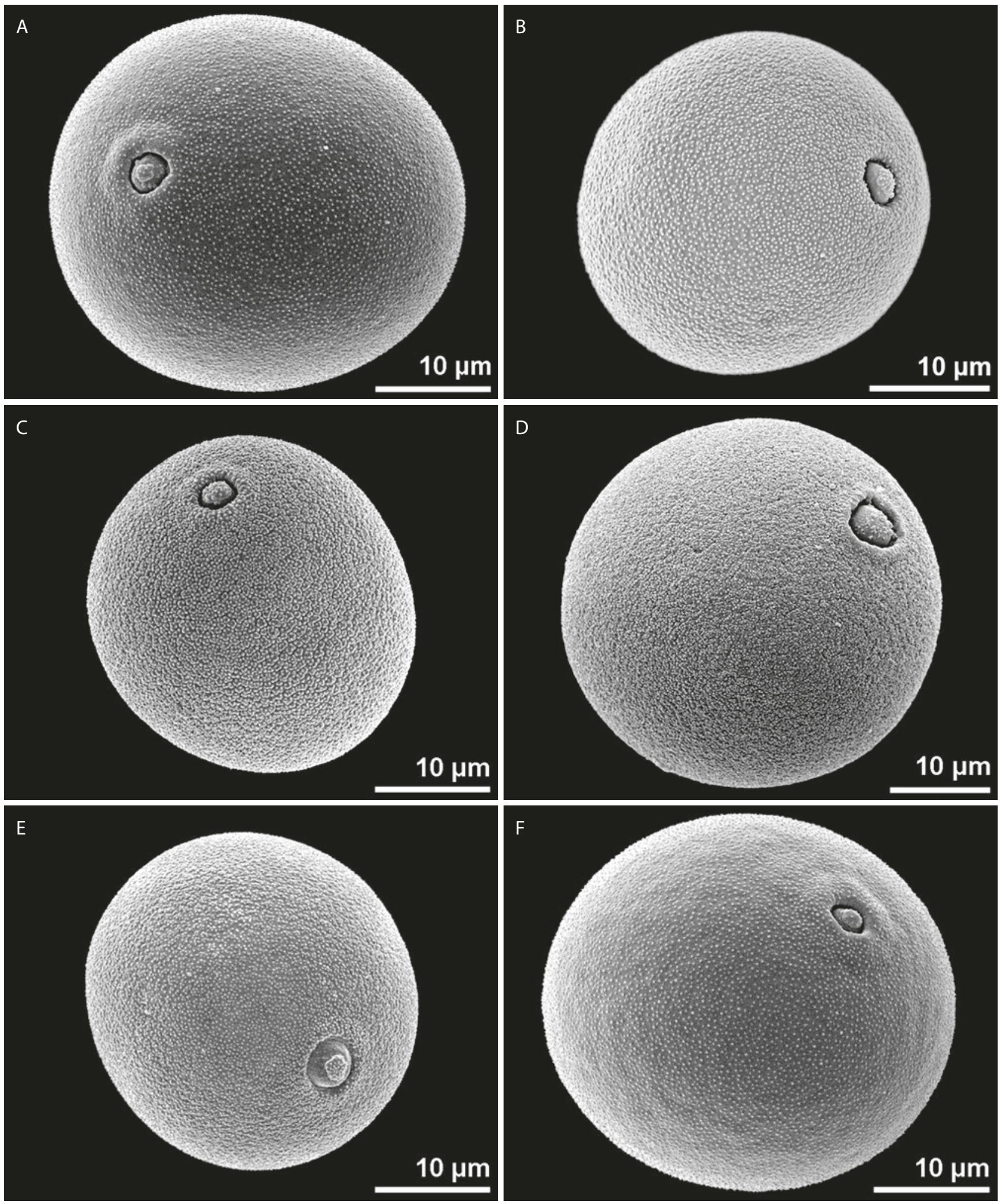

Fig. 8 Stenopalynous taxa (family level). Pollen of different Poaceae all look very similar, for example in Alopecurus (A), Cutandia (B), Dactylis (C), Fargesia (D), Poa (E), Sesleria (F) the pollen is spherical, ulcerate with nano-sized sculpture elements 

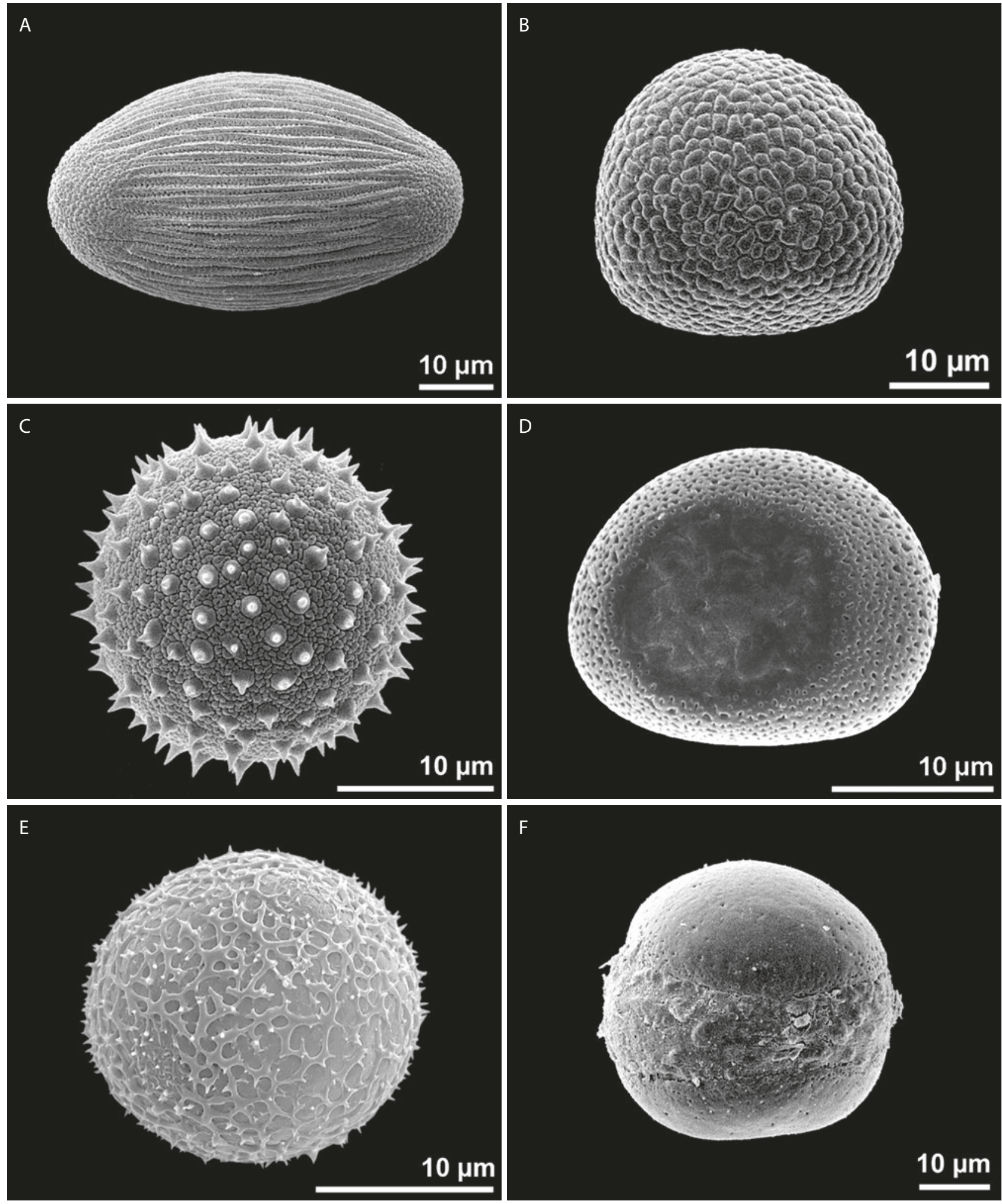

F

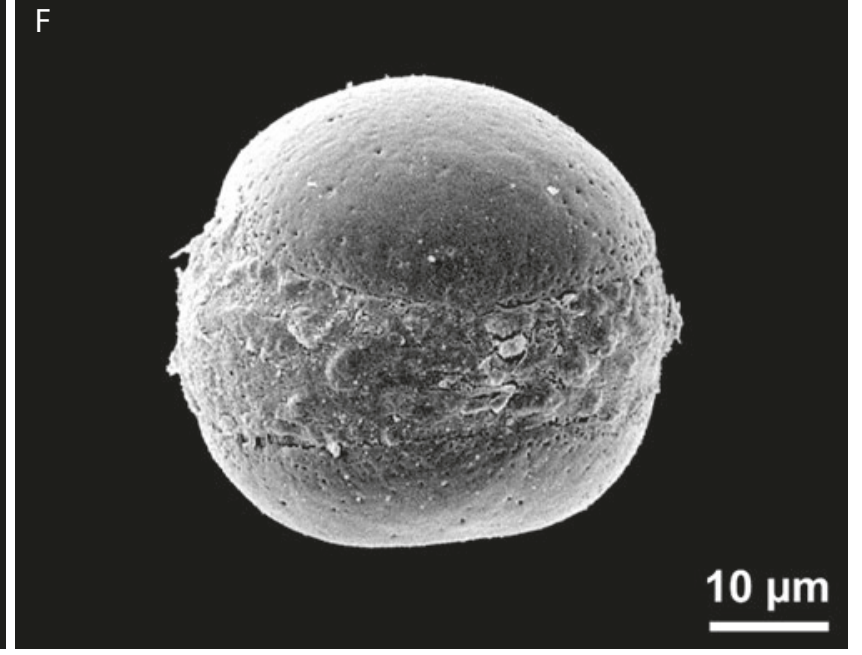

Fig. 9 Eurypalynous taxa (family level). A-F. Pollen of different Araceae genera look very different. A. Ambrosina pollen is plicate and inaperturate. B. Dracunculus pollen is verrucate and inaperturate. C. Pinellia pollen is echinate and inaperturate. D. Cyrtosperma pollen is reticulate and ulcerate. E. Anthurium pollen is reticulate-microechinate and diporate. F. Monstera pollen is psilate, with ring-like aperture 
appear somewhat "poor" regarding the diversity of pollen features (Hesse et al. 2000). In general, the richness and variation of morphological features in pollen decreases in eudicots (Furness and Rudall 1999a). In Alismatales, many pollen features are adaptive and related to their aquatic/semiaquatic habitat, e.g., thin-walled, inaperturate pollen have evolved iteratively, even filamentous pollen is not rare (Furness and Banks 2010).

Fine example for adaptive and simultaneously systematic values is the ring-like aperture found especially in monocots, while only few occur in dicots. A ring-like aperture was probably the best way to a target-oriented harmomegathic movement, to contract or expand a large area adapted for pollen tube formation. This type of aperture might be relict of early angiosperms, before the advent of the "eudicot-tricolpates".

Examples for diagnostic features at lower taxonomic levels (family) are saccate pollen, typical for Pinaceae and Podocarpaceae. A small papilla is characteristic for Taxodioideae pollen (see "Illustrated Pollen Terms"). Another example for a strong phylogenetic signal comes from an aroid subfamily, the aperigoniate Aroideae (Araceae). They are characterized by several synapomorphies: inaperturate pollen, often with an outermost non-sporopollenin layer (exine absent) and a thick spongy endexine. The absence of callose in pollen development is the reason for this uncommon wall structure, that differs from all other currently known angiosperms (Anger and Weber 2006; Hesse 2006a, b).

At the lowest taxonomic level (genus, species) a combination of distinct morphological and structural features usually refers to a particular genus or species. Even very inconspicuous features can represent an example of systematic value, like the Pinus subgenus Strobus (Haploxylon) type and the Pinus subgenus Pinus (Diploxylon) type (see "Pollen Morphology and Ultrastructure"). Another example is the large genus Amorphophallus (Araceae), showing high diversity in ornamentation (e.g., Ulrich et al. 2017). As a result of the harmomegathic effect, the shape of pollen may change, which is enabled by the elasticity of the exine and infoldings of the apertures. The aperture type and arrangement may lead to characteristic infoldings. Therefore, the shape of pollen in dry state can be typical for a family or genus (e.g., Halbritter and Hesse 2004). For example, tricolporate pollen of the genus Chaenarrhinum (Plantaginaceae) is heteropolar. The heteropolarity is only apparent in dry condition. Also, tricolpate pollen of Lamiaceae is highly characteristic in dry condition: it is prolate, extremely flattened, and with apertures arranged in a very distinct manner (Fig. 10; see also "harmomegathic effect" in "Pollen Morphology and Ultrastructure").

\section{Future Perspective}

$\mathrm{N}$ owadays, palynology serves as an indispensable tool for various applied sciences such as systematics (Doyle and Endress 2010; Dransfield et al. 2008), melissopalynology (Jones and Bryant 1996), and forensics (e.g., Mildenhall et al. 2006; Bryant 2013; Weber and Ulrich 2016), but should also stand alone as a basic field in science. In general, compared to the sporophyte the male gametophyte in seed plants is poorly investigated. From ca. 260.000 to 422.000 plant species (e.g., Thorne 2002; Govaerts 2003; Scotland and Wortley 2003; The Plant List currently accepts 350.699 species) only about $10 \%$ have been studied with respect to pollen grain morphology, and regarding pollen ultrastructure it is even much less. Therefore, it is important to continue classical and more advanced palynological studies.

Despite the long tradition of palynology and its application in many fields, it should be considered why it is important and where it is heading in the near future. In the twenty-first century, no matter what role palynology will play, being a basic field of science or more probably a bundle of applied fields, a vital issue will be the increase of our knowledge of pollen grains and in this context the enhancement of pollen terminology. Online pollen databases (efficient in data storage, data transmitting and dissemination) will get more and more important for the exchange of pollen and spore information (for example, PalDat; Weber and Ulrich 2017). Journals are nowadays published simultaneously in print as well as in electronic format, both have manifold advantages and disadvantages. Nevertheless, illustrated monographs, like this one, will retain their role of detailed information and long-living documentation. 



Fig. 10 Characteristic shape of pollen in dry condition. A-B. Lamium maculatum, Lamiaceae, pollen in hydrated and dry condition. C-D. Microrrhinum minus, Plantaginaceae, pollen in hydrated and dry condition. E-F. Scutellaria baicalensis, Lamiaceae, pollen in hydrated and dry condition 


\section{References}

Anger E, Weber M (2006) Pollen wall formation in Arum alpinum. Ann Bot 97: 239-244

Blackmore S (1992) Scanning electron microscopy in palynology. In: Nilsson S, Praglowski J (eds) Erdtman's Handbook of Palynology. $2^{\text {nd }}$ edition, Munksgaard, Copenhagen, p. 403-431

Blackmore S (2000) The palynological compass: the contribution of palynology to systematics. In: Nordenstam B, El-Ghazaly G, Kassas M (eds) Plant Systematics for the $21^{\text {st }}$ Century. Portland Press, London, p. 161-177

Blackmore S, Wortley A, Skvarla JJ, Rowley JR (2007) Pollen wall development in flowering plants. New Phytol 174: 483-498

Blackmore S, Wortley AH, Skvarla JJ, Gabarayeva NI, Rowley JR (2010) Developmental origins of structural diversity in pollen walls of Compositae. Plant Syst Evol 284: 17-32

Bradley DE (1958) The study of pollen grain surfaces in the Electron Microscope. New Phytol 57: 226-229

Brown R (1828) A brief account of microscopical observations made in the months of June, July, and August, 1827, on the particles contained in the pollen of plants; and on the general existence of active molecules in organic and inorganic bodies. Richard Taylor, London

Brown R (1833) On the organs and mode of fecundation in Orchideae and Asclepiadeae. In: The miscellaneous botanical works by Robert Brown. The Ray Society, London (1866)

Bryant VM (2013) Pollen and spore use in forensics. In: Jamieson J, Moenssens A (eds) Wiley Encyclopedia of Forensic Science, $2^{\text {nd }}$ edition, John Wiley \& Sons Ltd, Chichester, U.K.

Camerarius R J (1694) Ueber das Geschlecht der Pflanzen (De sexu plantarum epistola). Uebersetzt und herausgegeben von M. Mobius. Ostwald's Klassiker der exakten Wissenschaften 105

Campbell DH (1897) A morphological study of Naias and Zannichellia. Proc Calif Acad, Bot 3(1): 1-70

Candolle AP, Sprengel K (1821) Elements of the philosophy of plants. Edinburgh, printed for William Blackwood

Cavolini F (1792) Zosterae oceanicae Linnei $A N H \Sigma I \Sigma$. Contemplatus est Philippus Caulinus Neapolitanus. Annis 1787 et 1791. Neapoli

Doyle JA (2012) Molecular and fossil evidence on the origin of Angiosperms. Ann Rev Earth Planet Sci 40: $301-$ 326

Doyle JA, Endress PK (2010) Integrating Early Cretaceous fossils into the phylogeny of living angiosperms: Magnoliidae and eudicots. J Syst Evol 48: 1-35

Dransfield J, UhI NW, Asmussen CB, Baker WJ, Harley MM. Lewis CE (2008) Genera Palmarum. The Evolution and Classification of Palms. Kew Publishing, Kew

Ducker S, Knox B (1985) Pollen and pollination: a historical review. Taxon 34: 401-419

Ehrenberg CG (1838) Über die Bildung der Kreidefelsen und des Kreidemergels durch unsichtbare Organismen. Abh Kgl Akademie Wiss Berlin 1838: 59-147

Ehrlich HG, Hall JW (1959) The ultrastructure of eocene pollen. Grana Palynol 2: 32-35

Erdtman $G$ (1943) An introduction to pollen analysis. Chronica Botanica, Waltham, Mass

Erdtman $G$ (1947) Suggestions for the classification of fossil and recent pollen grains and spores. Svensk Bot Tidskr 41: 104-114
Erdtman G (1952) Pollen Morphology and Plant Taxonomy. Angiosperms. Almqvist \& Wiksell, Stockholm

Erdtman G (1957) Pollen and Spore Morphology. Plant Taxonomy. Gymnospermae, Pteridophyta, Bryophyta. Almqvist \& Wiksell, Stockholm

Erdtman G (1969) Handbook of Palynology - An Introduction to the Study of Polllen Grains and Spores. Munksgaard, Copenhagen

Erdtman G, Dunbar A (1966) Notes on electron micrographs illustrating the pollen morphology in Armeria maritima and Armeria sibirica. Grana Palynol 6: 338-354

Erdtman G, Straka H (1961) Cormophyte spore classification. Geol Fören Förenhandl 83: 65-78

Erdtman G, Vishnu-Mittre (1956) On terminology in pollen and spore morphology. The Palaeobotanist 5: 109-111

Faegri K, Iversen J (1950) Textbook of modern pollen analysis. Munksgaard, Copenhagen

Faegri K, Iversen J (1989) Textbook of Pollen analysis. $4^{\text {th }}$ edition, John Wiley \& Sons, Chichester

Fernandez-Moran H, Dahl AO (1952) Electron microscopy of ultrathin frozen sections of pollen grains. Science 116: 465-467

Fischer H (1890) Beiträge zur vergleichenden Morphologie der Pollenkörner. Thesis, Breslau

Friis EM, Crane PR, Pedersen KR (2011) Early Flowers and Angiosperm Evolution. Cambridge University Press, Cambridge

Fritzsche J (1834) Ueber den Pollen der Pflanzen und das Pollenin. Ann Phys 108: 481-492

Fritzsche J (1837) Über den Pollen. Mém Sav Étrang Acad Sci Pétersbourg 3: 649-672

Furness CA, Banks H (2010) Pollen evolution in the earlydivergent monocot order Alismatales. Int J Plant Sci 171: 713-739

Furness CA, Rudall PJ (1999a) Microsporogenesis in Monocotyledons. Ann Bot 84: 475-499

Furness CA, Rudall PJ (1999b) Inaperturate pollen in monocotyledons. Int J PI Sci 160: 395-414

Furness CA, Rudall PJ (2004) Pollen aperture evolution - a crucial factor for eudicot success? Trends Plant Sci 9: $154-158$

Gabarayeva NI, Grigorjeva VV (2010) Sporoderm ontogeny in Chamaedorea microspadix (Arecaceae): selfassembly as the underlying cause of development. Grana 49: 91-114

Gabarayeva NI, Grigorjeva VV, Rowley JR (2010) A new look at sporoderm ontogeny in Persea americana and the hidden side of development. Ann Bot 105: 939-955

Gee CT (2001) The mangrove palm Nypa in the geologic past of the New World. Wetl Ecol Manag 9: 181-194

Gleditsch JG (1751) Essai d'une Fécondation artificielle, fait sur l'espèce de Palmier qu'on nomme, Palma dactylifera folio flabelliformi. - Histoire de l'Académie Royale des Sciences et Belles Lettres de Berlin année 1749: 103-108

Gleditsch JG (1765) Kurze Nachricht von einer künstlichen wohlgelungenen Befruchtung eines Palmbaumes im Königlichen Kräutergarten zu Berlin. - Vermischte Physikalisch-Botanisch-Ökonomische Abh 1: 94-104

Göppert HR (1837) De floribus in statu fossili, commentatio botanica. Thesis, Breslau

Göppert HR (1848) Über das Vorkommen von Pollen im fossilen Zustande. Neues Jahrbuch für Mineralogie, Geognosie, Geologie und Petrefaktenkunde 11:338340

Govaerts R (2003) How many species of seed plants are there? - a response. Taxon 52: 583-584 
Grew N (1682) The Anatomy of plants, with an idea of a philosophical history of plants, and several other lectures, read before the Royal Society. W. Rawlins, London

Grímsson F, Grimm GW, Zetter R, Denk T (2016) Cretaceous and Paleogene Fagaceae from North America and Greenland: evidence for a Late Cretaceous split between Fagus and the remaining Fagaceae. Acta Palaeobotanica 56: 247-305

Grímsson F, Grimm GW, Zetter R (2017a) Tiny pollen grains: first evidence of Saururaceae from the Late Cretaceous of western North America. Peer J 5:e3434 https://doi.org/10.7717/peerj.3434

Grímsson F, Kapli P, Hofmann C, Zetter R, Grimm GW (2017b) Eocene Loranthaceae pollen pushes back divergence ages for major splits in the family. PeerJ 5:e3373 https://doi.org/10.7717/peerj.3373

Grímsson F, Zetter R, Halbritter H, Grimm GW (2014) Aponogeton pollen from the Cretaceous and Paleogene of North America and West Greenland: Implications for the origin and palaeobiogeography of the genus. Rev Palaeobot Palynol 200: 161-187

Guignard L (1891) Nouvelles études sur la fécondation. Ann Sc Nat, Bot ser 7, 14: 163-296

Guignard L (1899) Sur les antherozoides et la double copulation sexuelle chez les végétaux angiosperms. Rev Gen Bot 11: 129-135

Halbritter H, Hesse M (2004) Principal modes of infoldings in tricolp(or)ate Angiosperm pollen. Grana 43: 1-14

Hao G, Chye M-L, Saunders RMK (2001) A phylogenetic analysis of the Schisandraceae based on morphology and nuclear ribosomal ITS sequences. Bot J Linn Soc 135: 401-411

Harley MM, Baker WJ (2001) Pollen aperture morphology in Arecaceae: application within phylogenetic analyses, and a summary of the fossil record of palm-like pollen. Grana 40: 45-77

Harley MM, Ferguson IK (1990) The role of the SEM in pollen morphology and plant systematics. In: Claugher D (ed) Scanning Electron Microscopy in Taxonomy and Functional Morphology. Syst Ass Special Volume 41: 45-68. Clarendon Press, Oxford

Hay WW, Sandberg PA (1967) The Scanning Electron Microscope, a major break-through for micropaleontology. Micropaleontology 13: 407-418

Hell SW (2009) Microscopy and its focal switch. Nature Methods 6: 24-32

Heslop-Harrison J (1975) The physiology of the pollen grain surface. Proc R Soc, London B 190: 275-299

Hesse M (2006a) Reason and consequences of the lack of a sporopollenin ektexine in Aroideae (Araceae). Flora 201: 421-428

Hesse M (2006b) Conventional and novel modes of exine patterning in members of the Araceae - the consequence of ecological paradigm shifts? Protoplasma 228: 145-149

Hesse M, Blackmore S (2013) Editorial: Preface to the Special Focus manuscripts. Plant Syst Evol 299: 101 1-1012

Hesse M, Weber M, Halbritter H (2000) A comparative study of the polyplicate pollen types in Arales, Laurales, Zingiberales and Gnetales. In: Harley MM, Morton CM, Blackmore S (eds) Pollen and spores: morphology and biology. Royal Botanic Gardens, Kew, p. 227-239

Hofmeister W (1849) Die Entstehung des Embryo der Phanerogamen. Friedrich Hofmeister, Leipzig

Hooke R (1665) Micrographia, or, Some physiological descriptions of minute bodies made by magnifying glasses, with observations and inquiries thereupon. Printed by Jo. Martyn and Ja. Allestry, London
Hyde HA (1955) Oncus, a new term in pollen morphology. New Phytol 54: 255

Iversen J, Troels-Smith J (1950) Pollenmorfologiske definitioner og typer. Pollenmorphologische Definitionen und Typen. Danm Geol Unders, ser 4, 3: 1-54

John JF (1814) Ueber den Befruchtungsstaub, nebst einer Analyse des Tulpenpollens. J Chem Phys 12: 244-252

Jones GD, Bryant VM Jr. (1996) Melissopalynology. In: Jansonius J, McGregor DC (eds) Palynology: principles and applications. American Association of Stratigraphic Palynologists Foundation, vol 3, AASP Foundation, Dallas, p. 933-938

Kesseler R, Harley MM (2004) Pollen. The hidden sexuality of flowers. Papadakis Publisher, London

Knox RB (1984) The pollen grain. In: Johri BM (ed) Embryology of Angiosperms. Springer, Berlin

Kölreuter JG (1761-1766) Vorläufige Nachricht von einigen das Geschlecht der Pflanzen betreffenden Versuchen und Beobachtungen. 4 Vol., Gleditsch, Leipzig

Kölreuter JG (1806) De antherarum pulvere. Nova acta Academiae Scientiarum Imperialis Petropolitanae 15: 359-398

Kölreuter JG (1811) Dissertationis de antherarum pulvere continuato. Mem Acad Sci Petersbourg 3: 159-199

Kremp GOW (1968) Morphologic Encyclopedia of Palynology. $2^{\text {nd }}$ edition, Arizona Press, Tucson

Lindley J (1836) A natural system of botany; or, A systematic view of the organization, natural affinities, and geographical distribution of the whole vegetable kingdom: together with the uses of the most important species in medicine, the arts, and rural or domestic economy (2 ${ }^{\text {nd }}$ edition), Longman, London

Linnaeus C (1750) Sponsalia plantarum. J. G. Wahlbom, Stockholm. Facs. edition, Rediviva No. 19, Stockholm 1971

Malpighi M (1901) Die Anatomie der Pflanzen. I und II Theil, London 1675 und 1679. Bearbeitet von M. Möbius. Ostwald's Klassiker der exakten Wissenschaften Nr. 120, pp. 163

Manten AA (1966) Half a century of modern palynology. Earth-Sci Rev 2: 277-316

Mendes MM, Dinis J, Pais J, Friis EM (2014) Vegetational composition of the Early Cretaceous Chicalhão flora (Lusitanian Basin, western Portugal) based on palynological and mesofossil assemblages. Rev Palaeobot Palynol 200: 65-81

Mildenhall DC, Wiltshire PEJ, Bryant VM (2006) Forensic palynology: Why do it and how it works. Forensic Sci Int 163: 163-172

Moore PD, Webb JA, Collinson ME (1991) Pollen analysis. $2^{\text {nd }}$ edition. Blackwell Scientific Publication, Oxford

Mühlethaler K (1953) Untersuchungen über die Struktur der Pollenmembran. Mikroskopie 8: 103-110

MühlethalerK (1955) Die Struktur einigerPollenmembranen. Planta 46: 1-13

Nadot S, Forchioni A, Penet L, Sannier J, Ressayre A (2006) Links between early pollen development and aperture pattern in monocots. Protoplasma 228: 55-64

Nägeli K (1842) Zur Entwicklungsgeschichte des Pollens bei den Phanerogamen. Orell, Füssli \& Comp., Zürich

Nawaschin S (1898) Resultate einer Revision der Befruchtungsvorgänge bei Lilium martagon und Fritillaria tenella. Bull Acad Imp Sci St. Petersbourg, ser. 5, 9: $377-382$

Pettitt JM, Chaloner WG (1964) The ultrastructure of the Mesozoic pollen Classopollis. Pollen Spores 6: 611-620

Potonié R (1934) I. Zur Morphologie der fossilen Pollen und Sporen. Arb Inst Paläobotanik Petrographie Brennsteine 4: $5-24$ 
Potonié R (1956) Synopsis der Gattungen der Sporae dispersae, I. Teil: Sporites. Beih Geol Jahrb 23: 1-103

Punt W, Blackmore S, Nilsson S, Le Thomas A (1994) Glossary of Pollen and Spore Terminology. LPP Foundation, Laboratory of Palaeobotany and Palynology, University of Utrecht, Utrecht. LPP Contributions Series 1

Punt W, Hoen PP, Blackmore S, Nilsson S, Le Thomas A (2007) Glossary of pollen and spore terminology. Rev Palaeobot Palynol 143: 1-81

Purkinje JE (1830) De Cellulis antherarum fibrosis nec non de granorum pollinarium formis: Commentatio phytotomica. Grueson, Breslau

Reille M (1992) Pollen et Spores d'Europe et d'Afrique du Nord. Laboratoire de Botanique Historique et Palynologie, Marseille

Reille M (1995) Pollen et Spores d'Europe et d'Afrique du Nord, Supplement 1. Laboratoire de Botanique Historique et Palynologie, Marseille

Reille M (1998) Pollen et Spores d'Europe et d'Afrique du Nord, Supplement 2. Laboratoire de Botanique Historique et Palynologie, Marseille

Reinsch P (1884) Micro-Palaeophytologia formationis carboniferae. Krische, Erlangen

Reitsma TJ (1970) Suggestions towards unification of descriptive terminology of angiosperm pollen grains. Rev Palaeobot Palynol 10: 39-60

Rowley JR, Flynn JJ (1966) Single-stage carbon replicas of microspores. Stain Technol 41: 287-290

Sarawichit P (2012) Pollen and orbicular walls of selected species of Justicieae (Acanthaceae) and their systematic significance. Thesis, University of Vienna

Schacht H (1856/59) Lehrbuch der Anatomie und Physiologie der Gewächse. 2 Vol., Müller, Berlin

Schopf JM (1957) Spores and related plant microfossils Paleozoic. In: Ladd HS (ed) Treatise on marine ecology and paleoecology 2, Paleoecology: Geological Scociety of America Memoir 67/2, p. 703-707

Schopf JM (1964) Practical problems and principles in study of plant microfossils. In: Cross, AT (ed) Palynology in oil exploration - A symposium: Society of Economic Paleontologists and Mineralogists Special Publication 11 , p. 29-57

Scotland RW, Wortley AH (2003) How many species of seed plants are there? Taxon 52: 101-104

Sprengel CK (1793) Das entdeckte Geheimnis der Natur im Bau und in der Befruchtung der Blumen. Vieweg, Berlin

Sprengel K (1804) Anleitung zur Kenntniß der Gewächse. In Briefen. Erste Sammlung, Kimmel, Halle

Stolze GH (1816) Der Pollen der Pflanzen in chemischer Hinsicht; nebst einer Analyse des Pollens der Haselnusstaude (Corylus avellana Linn.). Jahrb Pharm 17: 159-187

Strasburger E (1884) Neve Untersuchungen über den Befruchtungsvorgang bei den Phanerogamen als Grundlage für eine Theorie der Zeugung. Fischer, Jena

Stuessy TF (1979) Ultrastructural data for the practicing plant systematist. Am Zool 19: 621-635

Stuessy TF (2009) Plant Taxonomy: The Systematic Evaluation of Comparative Data. $2^{\text {nd }}$ edition, Columbia University Press, New York

Stuessy TF, Funk VA (2013) New trends in plant systematics - Introduction. Taxon 62: 873-875
Thorne RF (2002) How many species of seed plants are there? Taxon 51: 511-522

Thornhill JW, Matta RK, Wood WH (1965) Examining threedimensional microstructures with the scanning electron microscope. Grana Palynol 6: 3-6

Traverse A (2007) Paleopalynology. $2^{\text {nd }}$ ed, Springer, Dordrecht

Ulrich S, Hesse M, Bröderbaver D, Bogner J, Weber $M$, Halbritter H (2013) Calla palustris (Araceae): New insights with special regard to its controversial systematic position and to closely related genera. Taxon 62: $701-712$

Ulrich S, Hesse M, Bröderbauer D, Wong SY, Boyce PC (2012) Schismatoglottis and Apoballis (Araceae: Schismatoglottideae): A new example for the significance of pollen morphology in Araceae systematics. Taxon 61: 281-292

Ulrich S, Hesse M, Weber M, Halbritter H (2017) Amorphophallus: New insights into pollen morphology and the chemical nature of the pollen wall. Grana 56: $1-36$

Von Grotthuss T (1814) Analysis des Tulpensamenstaubs. J Chem Phys 11: 281-380

Von Mohl H (1835) Sur la structure et les formes des grains de pollen. Ann Sci nat 2. Ser., 3: 148-180, 220-236, 304-346

Von Post L (1916) Einige südschwedische Quellmoore. Bull Geol Inst Univ Uppsala 15: 219-278

Weber M, Ulrich S (2010) The endexine: a frequently overlooked pollen wall layer and a simple method for detection. Grana 49: 83-90

Weber M, Ulrich S (2016) Forensic Palynology: How pollen in dry grass can link to a crime scene. In: Kars $\mathrm{H}$, van den Eijkel L (eds) Soil in Criminal and Environmental Forensics: Proceedings of the Soil Forensics Special, 6th European Academy of Forensic Science Conference. The Hague, Springer, p. 15-23

Weber M, Ulrich S (2017) PalDat 3.0 - second revision of the database, including a free online publication tool. Grana 56: 257-262

Wodehouse RP (1928) The phylogenetic value of pollen grain characters. Ann Bot 42: 891-934

Wodehouse RP (1935) Pollen grains. Their structure, identification and significance in science and medicine. McGraw-Hill, New York

Zetter R, Hofmann C (2001) New aspects of the palynoflora of the lowermost Eocene (Krappfeld Area, Carinthia). In: Piller WE, Rasser MW (eds) Paleogene of the Eastern Alps. Österreichische Akademie der Wissenschaften, Schriftenreihe der Erdwissenschaftlichen Kommissionen 14, p. 473-507

Zetzsche F, Huggler K (1928) Untersuchungen über die Membran der Sporen und Pollen. I. 1. Lycopodium clavatum L. Ann Chem 461: 89-108

Zetzsche F, Kalt P, Leichti J, Ziegler E (1931) Zur Konstitution des Lycopodiumsporonins, des Tasmanins und des Lange-Sporonins. J Prakt Chem 148: 67-84

Zetzsche F, Vicari H (1931) Untersuchungen über die Membran der Sporen und Pollen II, Lycopodium clavatum L., Untersuchungen über die Membran der Sporen und Pollen III. Picea orientalis, Pinus silvestris L., Corylus avellana L. Helv Chim Acta 14: 58-67 
Open Access This chapter is licensed under the terms of the Creative Commons Attribution 4.0 International License (http://creativecommons.org/licenses/by/4.0/), which permits use, sharing, adaptation, distribution and reproduction in any medium or format, as long as you give appropriate credit to the original author(s) and the source, provide a link to the Creative Commons license and indicate if changes were made.

The images or other third party material in this chapter are included in the chapter's Creative Commons license, unless indicated otherwise in a credit line to the material. If material is not included in the chapter's Creative Commons license and your intended use is not permitted by statutory regulation or exceeds the permitted use, you will need to obtain permission directly from the copyright holder.

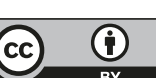

